Research Article

\title{
Conformity of Human Papillomavirus between Self-examination of Vaginal Fluid and Cervical Specimen with Fluid-Based Cytology in Precancerous Lesions
}

\author{
Tingkat Kesesuaian Human Papillomavirus antara Pemeriksaan Cairan \\ Vagina secara Mandiri dan Spesimen Serviks dengan Sitologi \\ Berbasis Cairan pada Lesi Prakanker
}

\author{
Rahmawaty Anwar, Syahrul Rauf, Eddy R. Moeljono \\ Department of Obstetrics and Gynecology \\ Faculty of Medicine Universitas Hasanuddin \\ Dr. Wahidin Sudirohusodo General Hospital \\ Makassar
}

\begin{abstract}
Objective: To determine the conformity of human papillomavirus between self-examination of vaginal specimen and cervical specimen with fluid-based cytology in precancerous lesions.

Methods: A cross-sectional study performed on cervical and vaginal fluid from 90 pre-cancerous lesions patients from April to September 2016. Cytological examination performed with self-examination and liquid-based cytology technique. HPV genotyping performed with PCR technique. Data were analysed with SPSS.

Results: Most of the women aged >35 years (89\%), 78\% $(71 / 90)$ multiparity and $74.4 \%(67 / 90)$ do not know about HPV screening. High-risk type found in both vaginal and cervical fluid was type 16,18, 33 and 45 whereas type 35 found only in vaginal fluid. The most prevalent high-risk HPV for both specimens were type 16 and 18 . HPV type 42 and 53 were the low-risk HPV found in the vaginal and cervical specimens (table 2). Cohen's kappa for inter-test agreement shows a strong correlation $(\mathrm{r}=0.864)$.

Conclusion: The HPV self-examination method can be used as a primary examination of cervical cancer lesions detection in addition to fluid-based cytology with the similar results.

[Indones J Obstet Gynecol 2018; 6-4: 253-256]

Keywords: cervical cancer, fluid-based cytology, human papillomavirus, self-examination
\end{abstract}

\begin{abstract}
Abstrak
Tujuan: Untuk mengetahui tingkat kesesuaian antara pemeriksaan HPV mandiri dari spesimen vagina dan hasil pemeriksaan sitologi berbasis cairan dari spesimen serviks.

Metode: Penelitian cross-sectional dilakukan pada cairan serviks dan vagina dari 90 pasien lesi pra-kanker pada April sampai September 2016. Pemeriksaan sitologi dilakukan dengan pemeriksaan diri dan teknik sitologi berbasis cairan. Pemeriksaan genotip HPV dilakukan dengan teknik PCR. Data dianalisis dengan SPSS.

Hasil: Sebagian besar perempuan dalam penelitian ini berusia $>35$ tahun (89\%), 78\% (71/90) multiparitas dan 74,4\% (67/90) tidak mengetahui tentang skrining HPV. Tipe HPV risiko tinggi yang ditemukan pada cairan vagina dan serviks adalah tipe 16, 18, 33 dan 45 sedangkan tipe 35 hanya ditemukan pada cairan vagina. Tipe HPV risiko tinggi yang dominan untuk kedua spesimen adalah tipe 16 dan 18. HPV tipe 42 dan 53 adalah HPV risiko rendah yang ditemukan pada baik spesimen vagina maupun serviks. Kappa Cohen untuk tingkat kesesuaian antara pemeriksaan mandiri dan sitologi berbasis cairan menunjukkan korelasi kuat $(r=0,864)$.

Kesimpulan: Metode pemeriksaan HPV secara mandiri sendiri dapat digunakan sebagai pemeriksaan primer deteksi lesi kanker serviks selain sitologi berbasis cairan dengan hasil yang sama.

[Maj Obstet Ginekol Indones 2018; 6-4: 253-256]

Kata kunci: human papillomavirus, kanker serviks, pemeriksaan mandiri, sitologi berbasis cairan
\end{abstract}

\section{INTRODUCTION}

Cervical cancer is the third most common cancer and the fourth leading cause of cancer in the world. It is estimated that 530,000 women diagnosed with cancer and 275.000 of them died in 2008 around the world.1,2 The development of cervical cancer is very difference between developed countries and developing countries. Globally, there were approximately $85 \%$ of cases and $88 \%$ of deaths from cervical cancer in developing countries. ${ }^{3}$ In countries that do not have a good screening program, most of the cervical cancer patients came at an advanced stage, and in an incurable stage. ${ }^{4}$ It is estimated that $50-80 \%$ of sexually active women will be infected with HPV in their life, and $80 \%$ will be free of infection within 2 years and will not cause cancer. ${ }^{4,5}$ Cervical cancer is the only cancer that can be detected early 
and inhibit its development.

The most important thing in HPV examination is the accuracy and level of conformity of examination results. There are currently several types of methods for detecting HPV infections in the genital tracts such as conventional Pap smears, visual inspection with acetic acid (IVA), HPV DNA testing with cervical smears and tests of vaginal swabs. ${ }^{6}$ This study aimed to determine conformity of human papillomavirus between self-examination of vaginal fluid and cervical specimen with fluidbased cytology in precancerous lesions.

\section{METHODS}

This cross-sectional study was performed on cervical and vaginal fluid from 90 pre-cancerous lesions patients from April to September 2016 at Dr. Wahidin Sudirohusodo Hospital and its affiliated hospitals in Department of Obstetrics and Gynecology, Faculty of Medicine Universitas Hasanuddin. Cytological sampling performed with self-examination and liquid-based cytology technique. HPV genotyping performed with PCR technique (primer system MY09-MY11 (MY09/11) WI LTS-06 method) at the Kalbe Genomics (KalGen) Laboratory Jakarta Indonesia. Data were analysed with SPSS. This study was approved by the Health Research Ethics Committee of the Faculty of Medicine, Universitas Hasanuddin.

\section{RESULTS}

In the present study, self-examination and liquidbased HPV cytology were performed on 90 patients with precancerous lesions. Most of the women aged $>35$ years (89\%), 78\% (71/90) multiparity and $74.4 \%(67 / 90)$ do not know about HPV screening (Table 1).
Table 1. Samples Characteristic

\begin{tabular}{lcc}
\hline \hline \multicolumn{1}{c}{ Characteristic $(\mathbf{n = 9 0 )}$} & $\mathbf{n}$ & $\mathbf{\%}$ \\
\hline Age (years) & & \\
$20-34$ & 10 & 11.1 \\
$>35$ & 80 & 88.9 \\
Parity & & \\
Nulliparity & 19 & 21.1 \\
Multiparity & 71 & 78.9 \\
Knowledge about HPV screening test & & \\
No & 67 & 74.4 \\
Conventional pap smear & 23 & 25.6 \\
\hline \hline
\end{tabular}

High risk and low-risk HPV types were found both in the vagina and the cervix. High-risk type found in both specimens were type 16, 18, 33 and 45 whereas type 35 found only in vaginal fluid. The most prevalent high-risk HPV for both specimens were type 16 and 18 . HPV type 42 and 53 were the low-risk HPV found in the vaginal and cervical specimens (Table 2). Cohen's kappa for inter-test agreement was 0.864 (Table 3).

Table 2. HPV Type in Vaginal and Cervical Specimen

\begin{tabular}{ccccccc}
\hline \hline HPV & \multicolumn{2}{c}{ Vagina } & \multicolumn{2}{c}{ Cervix } & \multicolumn{3}{c}{ Vagina and cervix } \\
& $\mathbf{n}$ & $\mathbf{\%}$ & $\mathbf{n}$ & $\mathbf{\%}$ & $\mathbf{n}$ & $\mathbf{\%}$ \\
\hline & \multicolumn{7}{c}{ High risk } \\
16 & 31 & 34.4 & 30 & 33.3 & 30 & 33.3 \\
18 & 22 & 24.4 & 30 & 33.3 & 21 & 23.3 \\
33 & 3 & 3.3 & 2 & 2.2 & 2 & 2.2 \\
45 & 7 & 7.8 & 6 & 6.7 & 6 & 6.7 \\
35 & 1 & 1.1 & - & - & - & - \\
& & & Low risk & & \\
42 & 9 & 10 & 9 & 10 & 8 & 8.9 \\
53 & 7 & 7.8 & 6 & 6.7 & 6 & 6.7 \\
\hline \hline
\end{tabular}

Table 3. Concordance of HPV Type between HPV Self-sampling and Liquid-based Cytology

\begin{tabular}{|c|c|c|c|c|c|}
\hline \multirow{2}{*}{ HPV self-sampling } & \multicolumn{2}{|c|}{ Liquid-based cytology } & \multirow{2}{*}{ Total } & \multirow{2}{*}{$\mathbf{r}$} & \multirow{2}{*}{$\mathbf{p}$} \\
\hline & High-risk HPV (n) & Low-risk HPV (n) & & & \\
\hline High-risk HPV & 49 & 5 & 54 & \multirow{2}{*}{0.864} & \multirow{2}{*}{0.000} \\
\hline Low-risk HPV & 1 & 35 & 36 & & \\
\hline
\end{tabular}




\section{DISCUSSION}

Age is a major factor in HPV infection in cervical cancer. The prevalence of women aged 20 s infected with high and low-risk HPV between 20\%-40\%. ${ }^{7}$ The study also found that the highest HPV type 16 infection occurs at age 25-40 years compared to HPV type 18 for the same age group then the risk of infection decreases with age. ${ }^{8,9}$ Women aged $>35$ years with pre-cancerous lesions in the present study higher than women aged 20-34 years with the same diagnosis. A study by Sanner et al., found that $40 \%$ of women who do not participate in the screening programs in Sweden prefer to perform self HPV examination making this examination could reduce the incidence of cervical cancer by 25 $50 \%$ in postmenopausal women. ${ }^{10}$

We included sexually active women aged 20-55 years in our study. Sexually active young women would have a positive HPV test result, and 20s was the limit age for cervical cancer screening based on the pathogenesis of the disease. However, high-risk HPV type 16/18 decreases with age at diagnosis. Approximately $70 \%$ of young women newly infected with HPV and infection clearance occurs after 12 months whereas the age of 55 years decreased the effectiveness of cytological examination is known to decline in the elderly age group. A Randomized Trial in Screening to Improve Cytology (ARTISTIC) also found that the prevalence of HPV decreased $40 \%$ in age $20-24$ years, $12 \%$ (3539 years), and $7 \%$ ( $>50$ years). Abnormal biopsy examination represents CIN 1 and CIN 2/3. These criteria based on the manifestation of low-grade histological changes (CIN 1) in new high-risk HPV infection. This change is usually temporary, while in CIN 2/3 acts as a precursor of cervical cancer. High-grade CIN 2/3 lesions along with risk factors will increase the incidence of persistent high-risk HPV infection whereas the latest pap smear examination (last for three months) and histopathology are the last diagnostic and the gold standard for the whole examination. This examination directly impact on the results of diagnostic tests performed. $6,11-13$

Various methods for detecting and determining the type of HPV DNA have been widely introduced. The most commonly used inspection methods are hybrid capture 2 (HC2) and PCR. In this study, we used PCR GMP 09/11 method. The use of PCR methods has been shown to have higher sensitivity to detect high-risk HPV than HC2. According to one
RCT result, the GPM 09/11 amplification method shows very low sensitivity (49\%). ${ }^{14}$ Therefore, the use of similar methods is likely to lead to low levels of audit sensitivity.

By comparing the health cost effects of some cervical cancer screening strategies, a positive HPV test will be followed by cytologic examination. The combination of cytologic and HPV examinations simultaneously shows that the use of HPV DNA testing as a single primary screening tool or in combination with cytology provides more costeffectiveness than primary screening with cytology, as it may extend the screening interval. ${ }^{15}$ Based on the Canadian Cervical Cancer Screening Trial comparing the performance of human papillomavirus (HPV) testing and Papanicolaou cytology in 10.154 samples found that the sensitivity for both tests, when used at the same time, was $100 \%$ and the specificity was $92.5 \%{ }^{16}$ Further research by synergising the existing inspection modalities will improve diagnostic ability, so the accuracy and precision of the tool can be as expected. Improving the validity of the tool, to obtain the lowest possible false negative value will provide hope for clinicians to detect earlier an illness, so treatment and treatment can be given at an earlier stage and improve the prognosis of the disease.

The accuracy level of conformity with the results of this examination kappa test indicates that 0.864 results are obtained which means that $86.4 \%$ of results between self-examination and liquid-based cytology have very strong correlation. In a previous study assessing the sensitivity and specificity of diagnostic tests for independent HPV examination in detecting HPV in high-grade precursor lesions and cervical cancer showed sensitivity $56 \%$ and specificity $98 \%$. The results showed that the examination was only able to detect $56 \%$ of the abnormal group, and if the negative results of this examination $98 \%$ ensure the absence of disease. The study had negative predictive value of this examination for only $68 \%$ and positive predictive value of $96 \%$. Based on these results, it can be said that self-examination has the ability to ensure the positive results of $96 \%$, but the use of examination tools as an early detection tool requires high negative false results. The accuracy of this diagnostic test is $79 \%$. These results indicate that $79 \%$ of the results of the tests performed have the conformity of the results with the standard of all samples. Briefly stated that if a person is diagnosed negatively with HPV self-examination, then the 
possibility to get negative results in the pathological findings is $98 \%$.

\section{CONCLUSION}

The degree of conformity of HPV vaginal selfexamination and cervical fluid-based cytology in pre-cancerous lesions has suitability with very strong categories so that the HPV self-examination method can be used as a primary examination of cervical cancer lesions detection in addition to fluid-based cytology with the similar results.

\section{REFERENCES}

1. American College of Obstetricians and Gynecologists. Cervical Cancer in Adolescent: Screening, Evaluation, and Management. Obstet Gynecol. 2010; 116(2): 469-72.

2. Echelman D, Feldman S. Management of cervical precancers: a global perspective. Hematol Oncol Clin North Am. 2012; 26(1): 31-44.

3. Ferlay J, Shin HR, Bray F, Forman D, Mathers C, Parkin DM. Estimates of worldwide burden of cancer in 2008: GLOBOCAN 2008. Int J Cancer. 2010; 127(12): 2893-917.

4. Goldhaber-Fiebert JD, Stout NK, Salomon JA, Kuntz KM, Goldie SJ. Cost-effectiveness of cervical cancer screening with human papillomavirus DNA testing and HPV-16,18 vaccination. J Natl Cancer Inst. 2008; 100(5): 308-20.

5. Eperon I, Vassilakos P, Navarria I, Menoud PA, Gauthier A, et al. Randomized comparison of vaginal self-sampling by standard vs dry swabs for human papillomavirus testing. BMC Cancer. 2013; 13(22): 353.

6. Warren JB, Gullett H, King VJ. Cervical cancer screening and updated Pap guidelines. Prim Care. 2009; 36(1): 131-49.

7. Herrero R, Castle PE, Schiffman M, Bratti MC, Hildesheim A, et al. Epidemiologic profile of type-specific human papillomavirus infection and cervical neoplasia in Guanacaste, Costa Rica. J Infect Dis 2005; 191: 1796-807.
8. Tiggelaar SM, Lin MJ, Viscidi RP, Ji J, Smith JS. Age-specific Human Papillomavirus antibody and DNA prevalence: a global review. J Adolesc Health 2012; 50(2): 110-31.

9. de Sanjose S1, Wheeler CM, Quint WG, Hunt WC, Joste NE, et al. Age-specific occurrence of HPV16- and HPV18-related cervical cancer. Cancer Epidemiol Biomarkers Prev. 2013; 22(7): 1313-8.

10. Sanner K, Wikström I, Strand A, Lindell M, Wilander E. Selfsampling of the vaginal fluid at home combined with highrisk HPV testing. Bri J Cancer. 2009; 101(5): 871-4.

11. Ronco G, Giorgi-Rossi P, Carozzi F, Confortini M, Dalla Palma $P$, et al. Efficacy of human papillomavirus testing for the detection of invasive cervical cancers and cervical intraepithelial neoplasia: a randomised controlled trial. Lancet Oncol. 2010; 11(3): 249-57.

12. Carozzi FM, Tornesello ML, Burroni E, Loquercio G, Carillo G, et al. Prevalence of human papillomavirus types in highgrade cervical intraepithelial neoplasia and cancer in Italy. Cancer Epidemiol Biomarkers Prev. 2010; 19(9): 2389-400.

13. Kitchener HC, Almonte M, Wheeler P, Desai M, Gilham C, at al. HPV testing in routine cervical screening: cross-sectional data from the ARTISTIC trial. Bri J Cancer. 2006; 95(1): 5661.

14. Torres-Ibarra L, Lazcano-Ponce E, Franco EL, Cuzick J, Hernández-Ávila M, et al. Triage strategies in cervical cancer detection in Mexico: methods of the FRIDA Study. Salud Publica Mex. 2016; 58(2): 197-210.

15. Goldhaber-Fiebert JD, Stout NK, Salomon JA, Kuntz KM, Goldie SJ. Cost-effectiveness of cervical cancer screening with human papillomavirus DNA testing and HPV-16,18 vaccination. J Natl Cancer Inst. 2008; 100(5): 308-20.

16. Isidean SD, Mayrand MH, Ramanakumar AV, Gilbert L, Reid SL, et al. Human papillomavirus testing versus cytology in primary cervical cancer screening: End-of-study and extended follow-up results from the Canadian cervical cancer screening trial. Int J Cancer. 2016; 139(11): 2456-66. 